\title{
Cutaneous Squamous Cell Carcinoma of the Head and Neck Pathologic TNM
}

\section{Finding v8}

National Cancer Institute

\section{Source}

National Cancer Institute. Cutaneous Squamous Cell Carcinoma of the Head and Neck Pathologic TNM Finding v8. NCI Thesaurus. Code C133196.

A pathologic finding about one or more characteristics of cutaneous squamous cell carcinoma of the head and neck, following the rules of the TNM AJCC v8 classification system. 